\title{
Official Discrepancies: Kosovo Independence and Western European Rhetoric
}

\author{
Branislav Radeljić \\ School of Law and Social Sciences, University of East London \\ (Correspondence Address: B.Radeljic@uel.ac.uk)
}

\begin{abstract}
This article examines approaches and official discrepancies characterising Western European rhetoric with regard to the Kosovo status question. Since the early 1980s, Kosovo has been increasingly present in European debates, culminating with the 1999 international intervention in the region and subsequent talks about its final status. Although the Kosovo Albanians proclaimed independence in February 2008 and the majority of EU Member States decided to recognise Kosovo as an independent state, Western European rhetoric has been rather divided. This article shows that in addition to five EU members who have decided not to recognise Kosovo from the very beginning, and thus are powerful enough to affect its further progress, both locally and internationally, some of the recognisers, although having abandoned the policy of 'standards before status', have also struggled to develop full support for the province - a discrepancy that surely questions the overall Western support for Kosovo's independence.
\end{abstract}

Key words: Kosovo independence, Serbs, Kosovo Albanians, European Union.

\section{Introduction}

Since the 1999 NATO-led involvement in then Federal Republic of Yugoslavia, Western countries have generally been inclined to provide Serbia's southern province of Kosovo with independence, often presenting it as the only way forward. Both Brussels and Washington officials have insisted that the Kosovo Albanians deserve to have their own state due to atrocities committed by the Serbian leadership over the last couple of decades. Following the 2008 unilateral declaration of independence by Kosovo, the persistence of two opposing expectations within the international community - that Kosovo will be recognised as soon as possible or that it will never become an independent state - has led to mounting confusion and disappointment about Kosovo's final status. The fact that the province is still 'neither here nor there' is capable of affecting its own as well as regional progress, especially with regard to the accession to the European Union.

Although often perceived by the Serbian leadership as being pro-Kosovo Albanian, however, the West is not fully united in discussions on Kosovo's status, economic performance, political climate, membership in international institutions, strategies and legislation to address social issues and so on. The discrepancies characterising Western European official rhetoric do not only exist between states that support Kosovo independence and states that object to it (as is the case in the European Union, with 23 of its Member States recognising the Kosovo state and five - Cyprus, Greece, Romania, Slovakia and Spain - rejecting to do so), but also within the states that were actually amongst the first recognisers. 
This article proves the existence of the above noted tendency by looking at official statements and reports (about the situation in Kosovo and decisions to recognise it) and, more precisely, by outlining the discrepancies existing between the dominant state representatives and their respective government departments (for example, in the United Kingdom, Germany and Italy). Accordingly, after a brief overview of the entry and presence of Kosovo in Western European rhetoric (through European Parliament debates), the article focuses on the post-1999 debates and arguments, with a particular emphasis being placed on the post-2008 official discrepancies. Apart from seeing such an approach as highly problematic, given its capacity to affect the international progress and reputation of Kosovo, the article encourages two substantial questions: 'To what extent do Western European countries and Western Europe, in general, support Kosovo being an independent state?' and 'What are the implications of the inconsistent Western approach?'

\section{Kosovo in Western European Rhetoric}

The archives of European Union institutions offer an important collection of documents about the relations between the then European Economic Community and the Yugoslav federation. Based on the available transcripts of European Parliament debates, Kosovo was mentioned for the first time in 1981, following the earlier riots, starting at the University of Priština and escalating into armed confrontations between Albanian students and the provincial police. ${ }^{i}$ During the debate, a Member of the European Parliament called 'the Foreign Ministers of the Member States meeting in political cooperation to express their concern to the Yugoslav government and to press for the Albanian section of the population of Yugoslavia to be guaranteed equal opportunities for development in economic, social, cultural and structural spheres' (European Parliament, 1981). Some later debates also expressed similar concerns (European Parliament, 1983; 1989). In fact, by the end of the 1980s, the Europeans had become aware of the differences and tensions existing within the Yugoslav federation. In Yugoslavia, the republics of Slovenia and Croatia, concerned about the future of the Titoist state and frustrated by the obligation to support its less-developed regions, had already fostered their own contacts with the West - a project taken even further due to the rise of Slobodan Milošević and growing dominance of the Serbian regime (Radeljić, 2012). In Kosovo, whose autonomy was revoked in 1989 and many Kosovo Albanian professionals dismissed from their positions, the situation became even more complex, resulting in the policy of peaceful resistance and establishment of unofficial parallel institutions. Following the outbreak of the Yugoslav state crisis and Slovenia and Croatia's declarations of independence in June 1991, the Kosovo Albanians decided to hold an unofficial referendum in September, to secure their own independence, and unofficial elections in May 1992, leading to the proclamation of the Republic of Kosovo (Krieger, 2001, p. 522).

Given that European involvement in the Yugoslav space in the early 1990s was primarily concerned with the events in Slovenia, Croatia and, even more problematically, Bosnia and Herzegovina, the Kosovo question seemed rather marginal. The fact that European Union representatives did not use the 1995 Dayton Peace Accords to also address the autonomous status of Kosovo was a serious matter of concern amongst Kosovo Albanians, interpreted as European disinterest in addressing their needs (Laakso, 2006, p. 152; Sell, 2002, p. 274; Toje, 2008, p. 52). Thus, leaving the Kosovo question unaddressed represented an opportunity for the 
Kosovo Liberation Army to criticise and ignore a pacifist doctrine of the Democratic League of Kosovo - an approach that generated a number of confrontations between local Albanians and Serbian forces. The failure of an approach promoted by the pro bono Public International Law and Policy Group, in late 1998 (suggesting to begin with an intermediate sovereignty, characterised by a phased reduction of Serbian control over the province of Kosovo that would in turn allow the local people to acquire sovereign authority, capable of protecting legitimate interests of the Serbian minority, and finish with a referendum on independence and pursuit of international recognition) and the escalation of conflict in January 1999 (when Serbian forces committed a crime against humanity by killing more than forty civilians in the village of Račak, in central Kosovo) ${ }^{\mathrm{ii}}$ were clear indicators that external involvement of some sort would be required. By this point, the West had become fully aware of its failure to at first prevent, and then deal with the consequences of the 1995 Srebrenica genocide and the artificially divided state of Bosnia and Herzegovina. According to Joschka Fischer, then German Foreign Minister, acting politely with Belgrade officials would lead only to more mass graves, so he stated that the use of force should be considered: 'I am not a friend of using force, but sometimes it is a necessary means of last resort. So I am ready to use it if there is no other way. If people are being massacred, you cannot mutter about having no mandate. You must act' (Fischer cited in Cohen, 1999). Such a standpoint was further approved and made even more official when the US Secretary of State Madeline Albright visited the Rambouillet peace talks, launched to negotiate settlement between the two opposing sides, and stressed: 'Let me say that if the talks crater because the Serbs do not say "Yes", we will have bombing. If the talks crater because the Albanians do not say "Yes", we will not be able to support them and in fact, will have to cut off whatever help they are getting from outside' (War in Europe, 2000).

The existing literature accompanying the 1999 Kosovo war has focused on all sorts of aspects, including the overall context (Bieber \& Daskalovski, 2005; Buckley \& Cummings, 2001; Judah, 2002; Kostovicova, 2005; Mertus, 1999; Phillips, 2012), the legality and consequences of the 1999 NATO involvement (Croft \& Williams, 2006; Falk, 1999; Glennon, 1999; Steinberg, 1999; Wedgwood, 1999), the postinterventionist positions (Bacevich \& Cohen, 2001; Bellamy, 2002; Daalder \& O'Hanlon, 2000; Ker-Lindsay, 2009; Lambeth, 2001; Latawski \& Smith, 2003; Tomuschat, 2002; van Ham \& Medvedev, 2002) and the proclamation of independence and international recognition (Borgen, 2010; Hilpold, 2012; Perritt, 2011; Summers, 2011; Weller, 2009). However, what the more recent accounts seem to have ignored to address relates to the implications of discrepancies characterising the Western European official rhetoric. The present lack of common position amongst the EU Member States does not only challenge the relations between them, but it also provides the Serbian authorities with an impression or, even more precisely, illusion that the Kosovo case could take a completely different direction and end up in their favour, as a constituent part of Serbia or, less desirably but still better than independence, as a province partitioned between the Serbs and the Kosovo Albanians. In addition, various government departments of the Western European countries that strongly support Kosovo's independence, have contributed to the overall complexity by often providing highly discrediting information about Kosovo that in turn encourages a whole set of questions with regard to EU policy-making.

\section{From the 'Standards before Status' to a Status without Standards}


Aware of the possible problems surrounding the implementation of its Resolution 1244, adopted in June 1999, the UN Security Council welcomed 'the work in hand in the European Union and other international organizations to develop a comprehensive approach to the economic development and stabilization of the region affected by the Kosovo crisis, including the implementation of a Stability Pact for South Eastern Europe with broad international participation in order to further the promotion of democracy, economic prosperity, stability and regional cooperation' (UNSC, 1999). As followed, the EU persuaded the international community to take part in the Stability Pact, launched the European Agency for Reconstruction in 2000 and introduced Stabilization and Association Process in 2001. The main task of these initiatives was to deal with instability in the Balkans and provide framework for stabilization and future development of the region.

At the time, Javier Solana, the EU's High Representative for Common Foreign and Security Policy, reminded the Kosovo Albanians that their independence was not on the agenda and that, technically, Kosovo was still part of Yugoslavia. He argued that the central assignment of international presence was to establish standards first and then discuss the final status (Radeljić, 2013, p. 24). However, the UN Interim Administration Mission in Kosovo (UNMIK), established by the Resolution 1244, did not manage to consolidate the political standards. The dialogue between the mission and Kosovo institutions was not productive. For example, the appointment of international judges proved insufficient due to the constant pressures by extremists in the predominantly Albanian environment, unwilling to cooperate in finding the perpetrators of ethnically motivated crimes; according to one report, there were only 15 international judges and 10 international prosecutors serving in the local justice system capable of dealing with only three percent of the criminal cases (Hartmann, 2003). In addition, as warned internationally, ' $[\mathrm{t}]$ he constant turnover and experience of staff in key positions undermined continuity and interrupted action on key initiatives' (ICG, 2003).

The two aspects that seriously questioned Western general sympathy for Kosovo independence in this period included the 'standards before status' approach, inaugurated by the third UNMIK chief, Michael Steiner of Germany, approved by the EU and welcomed by the Serbian authorities, and the expectations outlined during the EU-Balkans Thessaloniki summit in June 2003, expected to assess the region's performance and its European future. Although the 'standards before status' policy covered a whole range of issues, ranging from the establishment of democratic institutions and rule of law to the development of market economy and dialogue with Belgrade authorities, its essence 'was that it required Kosovo's institutions of selfgovernment to demonstrate that they were willing and able to protect the rights of all of Kosovo's ethnic communities, and had the capacity to act in a civilised way' (Ante, 2010, p. 150). Soon after, the EU-Balkans Thessaloniki summit, while noting that the future of the Balkans is in the EU, underlined that such a status will only be possible upon fulfilment of the same criteria used for the Central European states (EU Council, 2003). The fact that by this point the Europeans had started replacing the American dominant role in the Balkans was often perceived amongst the Kosovo Albanians as a European intention to suspend any political discussion about the Kosovo final status and, even more worryingly, to support the Serbian position vis-à-vis the Kosovo status. They understood that the autonomy they got as a result of the Resolution 1244 was, in fact, very limited (Mehmeti, 2013, pp. 197-198); even though elections were organised and Ibrahim Rugova, leader of the Democratic League of Kosovo, was 
elected president of Kosovo, what the Albanians really got was an illusion of self-rule (Gallagher, 2005, p. 154).

Once the EU had increased its presence, there was a general expectation that it would play a central role in the attempts determining the Kosovo's future status. As its representatives agreed, the whole process would be based on the following key principles: 'Kosovo must not return to the situation before March 1999 and Belgrade and Priština must move towards Euro-Atlantic integration; Kosovo's status must be based on multi-ethnicity, the protection of minorities, the protection of cultural and religious heritage, and effective mechanisms for fighting organised crime and terrorism; [t] he solution of Kosovo's status must strengthen regional security and stability; [a]ccordingly, there must be no change in the current territory of Kosovo (i.e. no partition of Kosovo and no union of Kosovo with any country or part of any country after the resolution of Kosovo's status); '[a]ny solution must be fully compatible with European values and standards and contribute to realizing the European Perspective of Kosovo and of the region; Kosovo will continue to need international civilian and military presences' (EU Council, 2005). The EU's decision to phrase its position by relying on numerous 'musts' served only to further irritate the conflicting parties. Their leaderships felt that the trust between them and the EU was losing its momentum and that while the Kosovo Albanians had to try to get rid of the policy of 'standards before status', the Serbs were resurrecting their nationalistic feelings, leading to the deterioration of cooperation with the International Criminal Tribunal for the former Yugoslavia and suspension of accession talks with the EU, in May 2006.

The advocacy of 'standards before status', although an ambitious attempt, was fully eroded and abandoned after the riots in mid-March 2004, ${ }^{\text {iii }}$ and replaced with a Standards Implementation Plan, with a particular focus on the economy, rule of law and dialogue between Belgrade and Priština. The international community, while positioned between the two opposing sides, understood that standards could not be satisfied any time soon, but also that lack of status and Kosovo's security were affecting the entire Balkan region. As one author put it, "[s]ince the end of the Kosovo conflict in summer 1999, the international community has wrestled with a dilemma. There is no prospect for genuinely sustainable stability in the region as long as the status of Kosovo has not been resolved. At the same time addressing this issue in itself presents considerable risks to stability. If the international community tackles the status issue without adequate preparation, deadlock at best and confrontation at worst might be the result. If it waited for too long the unstable elements on the ground, in particular the impatience of the Kosovar population, the persistent economic crisis and the still tense relations between the ethnic communities might well lead to a new crisis' (Lehne, 2004, p. 116).

If we analyse the positions existing at the time, we can argue that the international community or, more precisely, the European Union, although often presenting itself as a player that had accumulated a vast knowledge skill throughout the 1990s when encouraging the integration of the Central European states into its structures. By relying on this experience, the Brussels administration continued to insist on the processes of democratization and Europeanization, which for the locals, given the pending status of the province, had no significance whatsoever. Simply put, the gap between internationally promoted wishes and actual needs could not lead to structural reforms, economic prosperity, and employment, even though they were widely acknowledged as a powerful motivating force for future membership in the $\mathrm{EU}$; instead, the province continued to preserve its image of a black hole in the 
Balkans, extremely corrupt and involved in trans-national organised crime. With these aspects in mind, it is not surprising that the immediate post-Kosovo crisis literature has tended to present the Kosovo case as a real test for the EU, expected to provide the Albanian side with nothing but full independence of Kosovo and to accommodate the consequent Serbian frustration: 'It is difficult to see what participation in the affairs of Kosovo, if hardly any, there can be from the authorities in Belgrade. If it is possible to keep it within Serbia, regarding the status of Kosovo it can only be through a new version of autonomy, which allows the autonomous province most of the substance of independence without the formal status of diplomatic recognition and membership of the UN. It implies also that the armed forces of the bigger state to which they are attached will not be allowed access to the territory of the minority' (Dent, 2001, p. 124).

The Western European official rhetoric presented the infamous late-2005 Vienna talks as a point, aimed at resolving the final status of Kosovo. ${ }^{\text {iv }}$ As decentralisation was seen as capable of providing mechanisms to protect the minorities, the international mediators decided that the negotiation process between the Serbian and Kosovo Albanian representatives should begin with the very issue of decentralisation - already an important step given the earlier failure of a pilot project for the establishment of new municipalities in certain areas with Serbian majority (UNDP, 2006, p. 16). As followed, the January 2006 session was a complete failure; as observed afterwards, 'neither side ha[d] given an inch', meaning that 'relief agencies are preparing for the least-bad option - another exodus of Serbs' (Hundley 2006: 1). In February, the mediators failed again to reconcile the two sides over the issue of local government reforms; while the Serbian side insisted that government decentralization should be started as soon as possible, the Kosovo delegates maintained that this was possible only after determining Kosovo's status. During an even harder March round, the sides continued with their uncompromiseable views on government decentralisation in Kosovo. They discussed the problems of community financing, inter-communal cooperation, and the Serbian communities' ties with Serbia. In addition, the Serbian team suggested that the Serbian communities should, apart from the local tax revenues, be financed from the Serbia's national budget, while the Albanians argued that such an arrangemnt, like any other foreign aid, could enter Kosovo only through its central government.

The subsequent exchanges of standpoints focused on communal borders, religious facilities, property relations, economic problems as well as the need for international presence after the Kosovo status determination. Still, the two sides did not want to change their initially adopted positions. For example, Serbian Prime Minister Vojislav Koštunica underlined that 'the existence of Kosovo and Metohija as part of Serbia and the existence of the Serbian people in Kosovo are the key objectives of Serbia's involvement in the political talks for the future status of that region' and that any decision about Kosovo 'should be made within Serbia, in the framework of the large autonomy of Kosovo and Metohija within Serbia, while any other decisions - be it power decentralisation or autonomy status - are just its specifications' (Koštunica cited in Regnum, 2006). However, Koštunica affirmed that the Serbian government was ready to compromise to some extent and thus to provide the Kosovo province with 'a large autonomy - something between independence and European-standard autonomy'. By contrast, Kosovo President Fatmir Sejdiu expressed his delegation's 'hope that the process started in Vienna will be finished quickly and successfully so that this year [2006] can really become a year for 
determining Kosovo's status in conformity with the people's will - which is independence' (Sejdiu cited in Regnum, 2006).

The outcome of the expensive and time-consuming Vienna talks, which could have been predicted when it had become clear that the involved parties were not ready to compromise, confirmed the relevance of some previously offered arguments stating that a full independence of Kosovo could not be negotiated, but only imposed (Oberg $\&$ Mitić, 2005). However, the Western European rhetoric at the time - Solana and Rehn's decision to launch a new mission, under the EU's Common Security and Defence Policy, to provide Kosovo with support and assist it with necessary reforms ${ }^{\mathrm{V}}$ - presented the Europeans as interested in stabilizing the province so that it will be better prepared for its future status, while at the same hoping to see Serbian authorities focus on the country's progress towards EU membership rather than preservation of Kosovo within Serbian borders. The problem was that the Brussels administration, while it decided to ignore the German-launched policy of 'standards before status' so that it could move on with the Kosovo status question, it did not come up with any substantial offer or, even more appropriately, compensatory award for the Serbian side, but rather continued with its conditionality policy.

\section{2008: Proclamation of Independence and after}

The 2008 Kosovo declaration of independence should not be perceived as a big surprise, especially given that various members of Serbia's post-Milošević political elite, including the immediate prime minister Zoran Djindjić and some of his closest supporters, talked about the province of Kosovo as de facto independent and that Serbia had to focus on itself, meaning to move on with the processes of democratisation and Europeanisation. Still, the declaration was immediately challenged by the then Serbian leadership, resulting in an official call on the International Court of Justice (ICJ) to deliver an advisory opinion on whether Kosovo's unilateral declaration of independence was in accordance with international law. Both the declaration and the consequent court's opinion that the Kosovo Albanian move did not really violate international law encouraged a proliferation of literature concerned with its legal aspects and, equally important, implications for the international system and future secessionist attempts (Borgen, 2010; Fierstein, 2008; Hilpold, 2012; Vidmar, 2009). As one study correctly put it, '[t]he ICJ's ruling is nevertheless a strong card in the hands of Kosovo's political leadership in its quest for full recognition of its independence. It is also a relief to the states that have so far recognised Kosovo's independence. There are no signs yet that it will convince the other states in the international system that have so far refused to recognise Kosovo' (Noutcheva, 2012, p. 108).

Across the EU, a large majority of its Member States rushed to recognise the newly self-proclaimed Republic of Kosovo. To begin with, the United Kingdom fully ignored its previously adopted position '[d] escribing the standards for Kosovo as the only way forward towards final status', and clarifying that ' $[t]$ here was nothing automatic about the process. If Kosovo made the necessary progress in meeting the standards, it would continue to the next stage. But if not, it would have to undergo a further review' (UNSC, 2004). Although the standards-related talk had disappeared and the British government openly supported the establishment of a new state, some of its departments have continued to offer rather negative accounts of Kosovo, clearly generating a dilemma regarding the United Kingdom's general approach towards the 
Kosovo question. For example, the Foreign and Commonweal Office's section on travel and living abroad warns the potential travelers to Kosovo that the situation is 'tense', characterised by 'an underlying risk from terrorism' and occasional 'incidents of armed violence and vehicle explosions in major cities [that] are usually linked to organised crime' (FCO, 2013). However, in case they would still decide to go there, they should try to avoid Leposavić, Zvečan, Zubin Potok and the northern part of the city of Mitrovica, thus Serb-dominated areas, 'due to occasional violence there' (FCO, 2013). The Foreign Office's view largely corresponds to the one offered by the Red24, a London-based global security risk management group, suggesting 'a high degree of caution' when travelling to Kosovo and criticising the existing level of organised crime: 'Corruption and black market activities are prevalent in Kosovo, with well-established crime syndicates engaged in lucrative trades in narcotics and weapons, as well as human trafficking. The failure to establish fundamental rule of law during the country's transition to independence has allowed these syndicates to develop links to and collude with legitimate business enterprises, key state institutions and even public office holders. There are also strong connections between organised crime leaders and the large Albanian diaspora elsewhere in the world, especially in neighbouring Albania' (Red24, 2013).

Similarly to the British, the German government, although clearly aware of the scale of organised crime activities and its detrimental effect on the stabilisation of post-1999 Kosovo (IEP, 2007), abandoned the idea of standards and rushed to recognise Serbia's southern province as an independent state. Like the Foreign and Commonwealth Office, the German Federal Foreign Affairs has provided almost the same description and advice to potential travelers or even investors, warning that Kosovo is a country with many privately owned arms that are easily used, although, as underlined, not against the foreigners (Federal Foreign Office, 2013). Again, Italian official understanding of the situation in Kosovo is very similar to the previous two, leaving an impression that one should almost avoid going to Kosovo (Farnesina, 2013).

In contrast to the aforementioned EU Member States, who have recognised Kosovo, but remained rather suspicious about its settlement and future progress, there are five members who have rejected to follow the post-February 2008 trend of recognising Kosovo's independence. For example, Romania has decided to stay firm and not to compromise its initial rhetoric, advocating that 'the [Security] Council should give no consideration to any future status for the province until the standards spelled out by the international community become effective. The standards were not mere technical benchmarks; those were the measure of Kosovo's transformation into an area offering safety and opportunities to all its inhabitants and into an area that was no longer a threat to regional stability. What was at stake was not only the status of a province, but that of each and every member of its population' (UNSC, 2004).

Thus, from the present perspective, it is possible to argue that the introduction and subsequent abandonment of the policy of 'standards before status' have generated a number of puzzling issues, both at EU and local levels. First, such a policy outlined the existence of inconsistencies concerning the overall EU standpoint, leaving space for speculations how and why it has been impossible to speak with a single voice. Even though the majority of individual EU Member States' governments have recognised Kosovo, the post-2008 EU Progress Reports have portrayed Kosovo as extremely problematic - an aspect that easily questions the individual recogniser's approach. As one of the reports observed, 'Kosovo has to make further progress in establishing and consolidating the rule of law and needs to improve the functioning 
and independence of its judiciary. It needs to establish a track record in the fight against corruption, money laundering and organised crime, demonstrating concrete results. Kosovo also needs to strengthen the capacity, independence and professionalism of its public administration and improve its business environment, including regulation, supervision and corporate governance. Kosovo has to ensure full transparency in senior public appointments and make sure that public procurement complies with criteria of independence, objectivity and transparency. Kosovo needs to establish a sustainable macro-economic and fiscal policy ... Kosovo needs to improve the protection of Serb and other minorities and enhance dialogue and reconciliation between the communities' (European Commission, 2009, p. 5). Similarly, the later reports outlined a whole range of problems, ranging from 'weaknesses in tax and expenditure policies and, in law enforcement, including the fight against corruption and organised crime' (European Commission, 2011, p. 31) to the lack of capacity 'to improve implementation of the existing legal framework and enforcement of decisions remedying human rights infringements' (European Commission, 2013, p. 14).

Second, the problematic policy provided EU Member States, namely the ones who have rejected to recognise Kosovo, with an opportunity to prevent or, at least, postpone secessionist attempts at home. Based on various debates, their position has been largely criticised by the 23 recognisers: for example, Ulrike Lunacek, a Member of the European Parliament from Austria goes as far as to state that the five should be forced to recognise Kosovo, but then clearly outlines various problems they can use as a justification as to why not to do it: "The relative weakness of the Kosovo government, after fraudulent elections and a prolonged process for the voting and inauguration of the new President and the formation of government in the spring of 2011, as well as organised crime allegations by Dick Marty's report in the Parliamentary Assembly of the Council of Europe, do not give Prime Minister Thaçi the argumentative standing and power that he would need in order to show the necessary strength in the diplomatic arena and at home' (Lunacek, 2012, p. 151).

Locally, the whole 'standards before status' discourse has irritated the Kosovo Albanians as they understood that their status would not be resolved as quickly as they had initially thought. Official statements, delivered by the Brussels administration as well as individual EU governments have supported the presence of the EU Rule of Law Mission in Kosovo (EULEX), due to the risks of escalation of conflict - an initiative welcomed by the local Albanians. However, the fact that its performance proved to be quite handicapped, mostly in relation to police, justice and customs matters (Greiçevci, 2011), made it very difficult for the Albanians to identify themselves with their own, independent, state. As Ilir Deda, the director of Kosovar Institute for Policy Research and Development, has put it, 'five years ago, no one would have though that today Kosovo would not be a UN member, that we would not have a national football team and that we would be stuck in negotiations with Serbia ... Many people think that Kosovo has not been given its fair chance yet. May it be the UEFA [Union of European Football Associations], the Eurovision Song Contest or the Council of Europe - for a membership in almost all international organisations, Kosovo is still sitting in the waiting room' (Die Zeit, 2013).

Finally, the Serbian leadership, fully aware of the international as well as Kosovo Albanian positions, has perceived 'standards before status' as a valid policy to insist on and try to postpone the overall settlement of the Kosovo status. More importantly, the fact that Kosovo has not been given a UN seat yet or that it has not been recognised by all EU Member States has been interpreted as an additional 
opportunity, possibly resulting in a plan B. It is worth recalling that from the very beginning of the status talks, both Serbs and Kosovo Albanians presented themselves with a plan A only, meaning that one side would exit as an absolute winner and the other as an absolute loser. The international community played an important role in the formation of such uncompromisable approach. For example, it excluded partition based on the fact that it would imply forced population transfers to the northern or southern parts of the province, possibly accompanied by numerous clashes and casualties, and, it could be abused as a method of conflict settlement, capable of incentivising redrawing of borders elsewhere in the region, primarily in Bosnia and Herzegovina. In the end, the 'standards before status' approach was very much about Kosovo as multiethnic.

Considering everything outlined above, it is not difficult to conclude that post1999 Kosovo has struggled to meet various expectations, both locally and internationally. Still, even if the lack of capacity to satisfy some of the initially promoted standards fully becomes less problematic over time, ${ }^{\mathrm{vi}}$ a clear-cut status will be required, sooner rather than later, so that Kosovo's regional and international relations as well as memberships can be defined. As correctly observed by KerLindsay and Economides (2012, p. 85), '[w]here the question of Kosovo's status becomes more complex and will become a major issue is when Kosovo reaches a stage whereby it is ready to establish a more formal relationship with the European Union, such as through the actual conclusion of a formal Stabilisation and Association Agreement. Although this would appear to be a long way off, if the current stalemate within the EU persists then Kosovo's options for joining the EU would appear to be blocked'.

\section{Conclusion}

In contrast to the dominant expectations, the settlement of the Kosovo question has been rather slow, leaving the concerned parties bewildered. With a disputed proclamation of independence and without an already-long-awaited-for final status, it has become rather difficult to talk about the future of Kosovo. As demonstrated by the article, apart from the divisions characterising the Serb and Kosovo Albanian positions, the Europeans have also failed to offer a common position and strategy, capable of accommodating the Serbs, Kosovo Albanians, and, in fact, the whole Western Balkan region, even if such strategy would imply some painful compromises. This is an area where the question about the EU's sincere willingness to support the creation of an independent Kosovo gains its full validity. However, while analysing the situation in May 1999, thus before the end of the NATO bombing of Serbia, one author observed the following: 'Serbia will pay a high price for its attempted subordination and expulsion of the overwhelmingly Kosovar majority of its province. In the short term it is likely that there will be an increase in the number of refugees displaced from Kosovo. In the medium term there will be enormous costs in rebuilding the infrastructure of Serbia and Kosovo. It is likely that there will be a Greater Albania, as feared by the Former Yugoslav Republic of Macedonia and Greece. In the long term, NATO bombing without the use of ground force will point up the need for a European army if aggressive nationalism is to be deterred without resort to the destruction associated with air war. As America retreats from Europe, the states of Europe will have to go beyond calculations of national interest to assert a pan-European common interest in a milieu where both borders and groups are 
safeguarded subject to changes agreed by those affected, as in the case of German reunification' (Brewin, 2001, p. 88).

While going through the above outlined predictions, we can agree that Serbia has been paying a high price by not granting Kosovo an independent status and thus delaying its own progress towards the EU membership. As correctly predicted, in the short term, Serbs have increasingly left their enclaves, seeing them as a foreign territory in which they do not feel safe anymore. The ones who have stayed realised that they should be ready to cooperate and take part in Kosovo institutions; as explained elsewhere, '[t]his is owing to the fact that, not least because of its own parlous economic situation, exacerbated by the current global economic crisis, Serbia simply does not have the resources - or will not make them available - to support the southern enclaves economically' (Džihić \& Kramer, 2009, p. 9). Furthermore, the presence of the Albanian factor in Macedonia and Greece is often viewed as a synonym for instability and discussed in the context of a greater Albanian state, an ambition launched in 1878 by the League of Prizren, an Albanian political movement

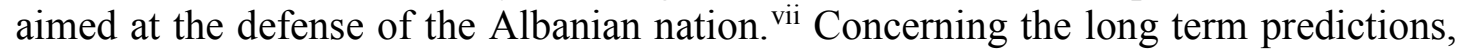
the Brussels administration will have to establish a common position and stick to it, otherwise the involvement of some other parties will be required. The ongoing inconsistencies within the EU itself suggest that 'the active engagement of the United States will be essential. Washington is still perceived by the Kosovars as their principal international backer' (Lehne, 2012, p. 13).

Today, half a decade after the proclamation of independence, when asked to assess the situation in Kosovo, its Albanian leadership tends to say that Kosovo is an indivisible state of big opportunities (Tanjug, 2013), while some other reports have clearly demonstrated that the overall situation in Kosovo is rather unstable and that many young people see no future there and, in fact, would like to leave (Deutsche Welle, 2013a). Needless to say, many observers have invested significant efforts to draft and recommend policies that, in their view, would work best so that the Kosovo question will be resolved and a new chapter in the history of Kosovo opened, ${ }^{\text {viii but }}$ what they all tend to undermine is the fact that the only durable solution will be the one that will manage to please both the Serbs and Kosovo Albanians, rather than alienate them further. With this in mind, the EU-brokered April 2013 Agreement between Belgrade and Priština - assessed as 'a landmark deal' by the EU representatives (European Union, 2013), 'the best possible offer' by Ivica Dačić, Serbia's prime minister (Politika, 2013), 'a first and historic agreement between Serbia and Kosovo' by Hashim Thaçi, Kosovo's prime minister (Deutsche Welle, $2013 \mathrm{~b}$ ), and as 'a landmark opportunity to improve human rights protection' by Human Rights Watch (2013) - could potentially be seen as a new chapter in the history of Kosovo, providing space for policy reconsiderations and, in fact, new political adjustments and durable solutions.

\section{Notes}

${ }^{\mathrm{i}}$ For a good overview of the riots, see P. F. R. Artisien \& R. A. Howells (1981) Yugoslavia, Albania and the Kosovo Riots, The World Today, 37(11), pp. 419-427.

ii For the description of the Račak massacre as a crime against humanity, see R. Bideleux \& I. Jeffries (2007) The Balkans: A Post-Communist History (Oxon: Routledge), p. 542; E. Gordy (2013) Guilt, Responsibility and Denial: The Past at Stake in post-Milošević Serbia (Philadelphia, PA: University of Pennsylvania Press), 
p. 7; D. Kritsiotis (2000) The Kosovo crisis and NATO's application of armed force against the Federal Republic of Yugoslavia, International and Comparative Law Quarterly, 49(2), pp 330-359.

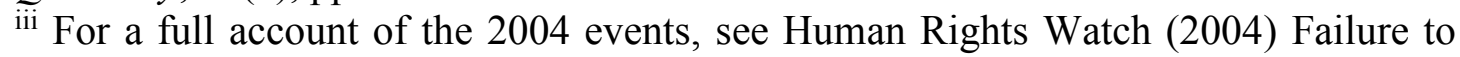
protect: Anti-minority violence in Kosovo, March 2004, 16(6D).

${ }^{i v}$ For a detailed analysis of the talks, see M. Weller (2008) The Vienna negotiations on the final status of Kosovo, International Affairs, 84(4), pp. 659-681.

v In addition, the International Crisis Group maintained that Kosovo should be allowed to have its own small army, supervised by NATO and focused on peacekeeping (ICG (2005) An army for Kosovo? Available at http://www.alertnet.org/thenews/newsdesk/ICG/2247ac5f9f9ac4e9cbbbeeb 13e5358bf.htm).

${ }^{v i}$ For an EU's softer tone with regard to the standards issue, see European Commission (2012) Communication from the Commission to the European Parliament and the Council on a Feasibility Study for a Stabilisation and Association Agreement between the European Union and Kosovo*, Brussels, 10 October 2012, $\operatorname{COM}(2012) 602$ final.

vii On different discussions of a Greater Albania, see R. C. Austin (2004) Greater Albania: The Albanian state and the question of Kosovo, 1912-2001, in: J. Lampe \& M. Mazower (Eds) Ideologies and National Identities: The Case of Twentieth Century Southeastern Europe, pp. 235-253 (Budapest: Central European University Press), J. Canak (Ed.) (1998) Greater Albania: Concepts and Possible Consequences (Belgrade: Institute of Geopolitical Studies), and P. Kola (2003) In Search of Greater Albania (London: C. Hurst \& Co.).

viii See, for example, International Crisis Group (2012) Kosovo and Serbia: A little goodwill could go a long way, Europe Report, No. 215, 2 February.

\section{References}

Ante, A. (2010) State Building and Development: Two Sides of the Same Coin? Exploring the Case of Kosovo (Hamburg: Disserta Verlag).

Bacevich, A. J. \& E. A. Cohen (Eds) (2001) War over Kosovo: Politics and Strategy in a Global Age (New York: Columbia University Press).

Bellamy, A. J. (2002) Kosovo and International Society (Basingstoke: Palgrave Macmillan).

Bieber, F. \& Ž. Daskalovski (Eds) (2005) Understanding the War in Kosovo. (London: Frank Cass).

Borgen, C. J. (2010) Advisory opinion, accordance with international law of the unilateral Declaration of Independence in respect of Kosovo, International Legal Materials, 49(5), pp. 1404-1440.

Brewin, C. (2001) Should NATO bomb Serbia?, in: M. Weller, K. Drezov \& B. Gökay (Eds) Kosovo: The Politics of Delusion, pp. 83-89 (London: Frank Cass). 
Buckley, M. \& S. N. Cummings (Eds) (2001) Kosovo: Perceptions of War and its Aftermath (New York: Continuum).

Cohen, R. (1999) Germany's pragmatic ex-radical thinks globally, The New York Times, 28 January.

Croft C. \& P. R. Williams (2006) Was the former 1999 NATO intervention an illegal war against the Former Republic of Yugoslavia?, in: A. Di Lellio (Ed.) The Case for Kosova: Passage to Independence, pp. 121-128 (London and New York: Anthem Press).

Daalder, I. H. \& M. E. O'Hanlon (2000) Winning Ugly: NATO's War to Save Kosovo (Washington, DC: The Brookings Institution).

Dent, M. (2001) Lessons of Kosovo, in: M. Weller, K. Drezov \& B. Gökay (Eds) Kosovo: The Politics of Delusion, pp. 120-130 (London: Frank Cass).

Deutsche Welle (2013a) Mladi bez perspektive na Kosovu, 16 February.

Deutsche Welle (2013b) Majorities in Kosovo, Serbia support new deal, 20 April.

Džihić, V. \& H. Kramer (2009) Kosovo After Independence: Is the EU's EULEX Mission Delivering on its Promises? (Berlin: Friedrich-Ebert-Stiftung).

EU Council (2003) EU-Western Balkans Summit, Thessaloniki, 21 June 2003: Declaration. Available at http://www.eu2003.gr/en/articles/2003/6/23/3135/index.asp? (accessed 10 February 2013).

EU Council (2005) Summary note on the joint report by Javier Solana, EU High Representative for the CFSP, and Olli Rehn, EU Commissioner for Enlargement, on the future EU Role and Contribution in Kosovo. 14 June. Available at http://www.consilium.europa.eu/ueDocs/cms_Data/docs/pressdata/en/reports/85228.p df (accessed 10 February 2013).

European Commission (2009) Communication from the Commission to the European Parliament and the Council: Kosovo* - Fulfilling its European Perspective. Brussels, 14 October. COM(2009)5343.

European Commission (2011) Kosovo* 2011 Progress Report. Brussels, 12 October. SEC(2011)1207.

European Commission (2013) Kosovo* 2013 Progress Report. Brussels, 16 October. SWD(2013)416.

European Parliament (1981) Motion for a resolution. 2 July. Brussels: Historical Archives of EU Institutions. 
European Parliament (1983) Debates of the European Parliament: Yugoslavia. 8 March. Brussels: Historical Archives of EU Institutions.

European Parliament (1989) Resolution on the situation in Kosovo. 13 April. Brussels: Historical Archives of EU Institutions.

European Union (2013) Serbia and Kosovo reach landmark deal. Available at http://eeas.europa.eu/top_stories/2013/190413_eu-facilitated_dialogue_en.htm (accessed 20 December 2013).

Falk, R. A. (1999) Kosovo, world order and the future of international law, American Journal of International Law, 93(4), pp. 847-857.

Farnesina (2013) Viaggiare sicuri: Kosovo. Available at http://www.viaggiaresicuri.it/?kosovo (accessed 17 February 2013).

FCO (2013) Kosovo. Available at http://www.fco.gov.uk/en/travel-and-livingabroad/travel-advice-by-country/europe/kosovo (accessed 15 February 2013).

Federal Foreign Office (2013) Kosovo: Reise und Sicherheitshinweise. Available at http://www.auswaertiges-amt.de/DE/Laenderinformationen/00-

$\mathrm{SiHi} /$ KosovoSicherheit.html (accessed 15 February 2013).

Fierstein, D. (2008) Kosovo's Declaration of Independence: an incident analysis of legality, policy and future implications, Boston University International Law Journal, 26, pp. 417-442.

Gallagher, T. (2005) The Balkans in the New Millennium: In the Shadow of War and Peace (London and New York: Routledge).

Glennon, M. J. (1999) The new interventionism: the search for a just international law, Foreign Affairs, 78(3), pp. 2-7.

Greiçevci, L. (2011) EU actorness in international affairs: the case of EULEX Mission in Kosovo, Perspectives on European Politics and Society, 12(3), pp. 283303.

Hartmann, M. E. (2003) International Judges and Prosecutors in Kosovo: A New Model for Post-Conflict Peacekeeping. USIP Special Report, October.

Hilpold, P. (Ed.) (2012) Kosovo and International Law: The ICJ Advisory Opinion of 22 July 2010 (Leiden: Brill).

Human Rights Watch (2013) Serbia-Kosovo: landmark opportunity for human rights. Available at http://www.hrw.org/news/2013/04/23/serbiakosovo-landmarkopportunity-human-rights (accessed 10 November 2013).

Hundley, T. (2006) Wary Serbs watch deadlocked talks on Kosovo's independence, Chicago Tribune, 10 June. 
ICG (2003) Two to tango: an agenda for the new Kosovo SRSG, Europe Report, No. 148,3 September.

IEP (2007) Operationalisierung von Security Sector Reform (SSR) auf dem Westlichen Balkan - intelligente/kreative Ansätze für eine langfristig positive Gestaltung dieser Region (Berlin: Institut für Europäische Politik).

Judah, T. (2002) Kosovo: War and Revenge (New Haven, CT: Yale University Press).

Ker-Lindsay, J. (2009) Kosovo: The Path to Contested Statehood in the Balkans (London and New York: I.B. Tauris).

Ker-Lindsay, J. \& S. Economides (2012) Standards before status before accession: Kosovo's EU perspective, Journal of Balkan and Near Eastern Studies, 14(1), pp. 7792.

Kostovicova, D. (2005) Kosovo: The Politics of Identity and Space (Oxon: Routledge).

Krieger, H. (Ed.) (2001). The Kosovo Conflict and International Law: An Analytical Documentation (Cambridge: Cambridge University Press).

Laakso, L. (2006) A capability-implementation gap in the making? Multi-level governance and European crisis management, in: G. P. E. Walzenbach (Ed.) European Governance: Policy Making between Politicization and Control, pp. 147165 (Aldershot: Ashgate).

Latawski, P. \& M. A. Smith (2003) The Kosovo Crisis and the Evolution of Post-Cold War European Security (Manchester: Manchester University Press).

Lehne, S. (2004) Has the "Hour of Europe" come to last? The EU's strategy for the Balkans, in: J. Batt (Ed.) The Western Balkans: Moving on, pp. 111-124 (Paris: Institute for Security Studies).

Lehne, S. (2012) Kosovo and Serbia: toward a normal relationship, Carnegie Policy Outlook, March.

Lunacek, U. (2012) Kosovo-Serbia: will they ever come to terms? What is the European Union's role?, in: V. Džihić \& D. Hamilton (Eds) Unfinished Business: The Western Balkans and the International Community, pp. 149-157 (Washington, DC: Center for Transatlantic Relations).

Mehmeti, L. I. (2013). Democratization in Kosovo: The role of international institutions, in: B. Radeljić (Ed.) Europe and the Post-Yugoslav Space, pp. 183-209 (Farnham: Ashgate).

Mertus, J. A. (1999). Kosovo: How Myths and Truths Started a War (Berkeley, CA: University of California Press). 
Noutcheva, G. (2012) European Foreign Policy and the Challenges of Balkan Accession: Conditionality, Legitimacy and Compliance (Oxon: Routledge).

Oberg, J. \& A. Mitić (2005) Kosovo: Many options but independence. Available at http://www.transnational.org/pressinf/ 2005/pi228_Oberg_Mitic_Kosovo.html (accessed 10 February 2013).

Perritt, H. H. (2011) The Road to Independence for Kosovo: A Chronicle of the Ahtisaari Plan (Cambridge: Cambridge University Press).

Phillips, D. L. (2012) Liberating Kosovo: Coercive Diplomacy and US Intervention (Cambridge, MA: The MIT Press).

Politika (2013) Dačić: Najbolja ponuda dosad, međunarodno priznat sever, 20 April. Available at http://www.politika.rs/rubrike/tema-dana/Dacic-Ocekujem-konsenzus-oponudi-iz-Brisela.lt.html (accessed 10 December 2013).

Radeljić, B. (2012) Europe and the Collapse of Yugoslavia: The Role of Non-State Actors and European Diplomacy (London and New York: I. B. Tauris).

Radeljić, B. (2013) Europe and the post-Yugoslav space: from intervention to integration, in: B. Radeljić (Ed.) Europe and the Post-Yugoslav Space, pp. 1-32 (Farnham: Ashgate).

Red24 (2013) Kosovo: country intelligence. Available at http://www.red24.com/members/intelligence/kosovorepublic.php (accessed 10 February 2013).

Regnum (2006) Vienna talks: Albanians don't hurry to recognise the rights of Serbs in Kosovo, 29 March. Available at http://www.regnum.ru/english/613129.html (accessed 7 February 2013).

Sell, L. (2002) Slobodan Milošević and the Destruction of Yugoslavia (Durham, NC: Duke University Press).

Steinberg, J. B. (1999) A perfect polemic: blind to reality on Kosovo, Foreign Affairs, 78(6), pp. 128-133.

Steiner, M. (2002) Speech to Donors' Conference. Brussels, 5 November. Available at http://www.unmik online.org/press/2002/pressr/pr864.htm (accessed 7 February 2013).

Summers, J. (Ed.) (2011) Kosovo: A Precedent? The Declaration of Independence, the Advisory Opinion and Implications for Statehood, Self-Determination and Minority Rights (Leiden: Martinus Nijhoff Publishers).

Tanjug (2013) Jahjaga: Kosovo država velikih mogućnosti, 16 February. 
Toje, A. (2008) America, the EU and Strategic Culture: Renegotiating the Transatlantic Bargain (Oxon: Routledge).

Tomuschat, C. (2002) Kosovo and the International Community: A Legal Assessment (Alphen aan den Rijn: Kluwer Law International).

UNDP (2006) Early Warning Report: Kosovo, No. 12.

UNSC (1999) United Nations Security Council Resolution 1244.

UNSC (2004) Implementing "Standards before Status" policy core political project for UN Kosovo Mission, Security Council told, Press Release, 6 February, SC/7999.

van Ham, P. \& S. Medvedev (Eds) (2002) Mapping European Security after Kosovo (Manchester: Manchester University Press).

Vidmar, J. (2009) International Legal Responses to Kosovo's Declaration of Independence, Vanderbilt Journal of Transnational Law, Vol. 42, pp. 779-851.

War in Europe (2000) A Documentary.

Wedgwood, R. (1999) NATO's campaign in Yugoslavia, The American Journal of International Law, 93(4), pp. 828-834.

Weller, M. (2009) Contested Statehood: Kosovo's Struggle for Independence (Oxford: Oxford University Press).

Die Zeit (2013) Kosovo ist als Staat noch Stückwerk, 14 February. Availably at http://www.zeit.de/politik/ausland/2013-02/kosovo-5-jahre-unabhaengigkeit (accessed 16 February 2013). 